\title{
The Spread of Chinese Virus in the Internet Discourse: A Cognitive Semantic Analysis
}

\author{
Rafat Augustyn \\ rafal.augustyn@poczta.umcs.lublin.pl \\ Department of Applied Linguistics, \\ Maria Curie-Skłodowska University in Lublin, Poland \\ Ewelina Prażmo \\ ewelina.prazmo@poczta.umcs.lublin.pl \\ Department of English and General Linguistics, \\ Maria Curie-Skłodowska University in Lublin, Poland
}

\begin{abstract}
In the present paper we examine the use of non-technical terms used to refer to the SARS-Cov2 virus, which - in a deliberate or non-deliberate fashion - stress the place of the virus' origin. In particular, we consider the three following terms: Chinese virus, Wuhan virus, and Asian virus. Drawing on the cognitive semantics methodology, in particular, the notion of meaning potentials (Norén \& Linell, 2007) and conceptual blending theory (Fauconnier \& Turner, 2003; Brandt \& Brandt, 2005; Oakley \& Coulson, 2008) we aim to investigate the dynamics of meaning construal of the selected expressions in English-language Internet discourse. The main objective is to account for different interpretations of the same expressions as they are used in different contexts with, presumably, various intentions. Complex expressions such as compounds, tend to exhibit various meanings and thus, can be said to possess different meaning potentials which are activated differently depending on the contextual circumstances in the process of meaning construal, which - as we want to show in our analysis - is not always so intuitive. In this paper we thus argue that only a pragmatically-enriched model of dynamic meaning construal can account for the polysemy and frequent ambiguity of compound expressions, including semantic extensions with generally derogatory or even outright racist connotations.
\end{abstract}

Keywords: meaning potentials; conceptual integration; racist discourse; COVID-19; Chinese virus

\section{INTRODUCTION}

Late 2019 saw the emergence of a new virus, later termed the SARS-CoV-2 virus. Severe Acute Respiratory Syndrome (SARS)-CoronaVirus (CoV)-2 is a new virus belonging to the coronavirus family, the seventh coronavirus recognised as a human pathogen. It was first hypothesised to have been transmitted from livestock to people in Huanan Seafood Wholesale Market in Wuhan, Hubei province in China. Then, it has spread to other regions of China and subsequently to other parts of the world to finally cause a global pandemic of an unprecedented scale. Alongside SARS-CoV-2 virus (henceforth referred to, simply, as "the virus"), media coverage of the news related to the virus and the disease it may cause (COVID-19) started spreading all over the globe since late January 2020 as the World Health Organisation declared COVID-19 outbreak a public health emergency of international concern. SARS-CoV-2 as the name of the new virus and COVID-19 as the name of the disease it causes were announced by the ICTV and WHO respectively on 11 February 2020. (https://www.who.int/emergencies/diseases/novel-coronavirus-2019/technical-guidance/nami 
ng-the-coronavirus-disease-(covid-2019)-and-the-virus-that-causes-it; accessed on 5 August 2020). Particularly since 11 March 2020, as the WHO officially recognised the outbreak as a pandemic, the coronavirus-related discourse has occupied headlines and front-pages of all the global leading newspapers and has been the main topic of all major TV broadcasters and social media.

\section{STATEMENT OF THE PROBLEM}

The virus is not, however, referred to exclusively by its official name. For reasons of convenience, it is often referred to simply as "the virus", "the coronavirus", or even "the corona". There are, nonetheless, also other expressions which, either because of the speaker's/writer's deliberate choice or mindless repetition, profile the "Chinese nature" of the virus. The potential problems related to using such politically-charged or even openly xenophobic expressions as names of SARS-CoV-2 have been already recognised (AlAfnan, 2020; Budhwani \& Sun, 2020; Chen, Lyu, Yang, Wang, \& Luo, 2020; Gee, Ro, \& Rimoin, 2020; Tabri, Hollingshead, \& Wohl, 2020; Ziems, He, Soni, \& Kumar, 2020). In one of the studies, AlAfnan (2020) claims that proper reading of media texts requires "critical discourse analysis in terms of interpretation and contextual knowledge to properly read the explicit and implicit meaning intended by writers" (AlAfnan, 2020, p. 60). In the present paper we echo this view and attempt to put special emphasis on background knowledge concerning the virus and its origin on the one hand, and being aware of various intentions behind the words produced by different speakers, on the other. Ziems at al. (2020) study anti-Asian hate speech as well as counterhate speech on Twitter in the context of the pandemic. They show that online antisocial behaviour such as hate speech, abuse, and trolling is socially contagious and thus harmful and prejudiced attitudes can spread quickly and easily. Chen et al. (2020) attempt to analyse realworld usage of the Chinese virus expression on Twitter and separate neutral usages from deliberately harmful ones which intentionally attach ethnicity to the virus. Their results suggest that "while the term 'Chinese virus' could be interpreted either as neutral or racist, its usage on social media leans strongly towards the latter" (Chen et al., 2020, p. 1). Likewise, Budhwani and Sun (2020) claim that "referencing the novel coronavirus as the "Chinese virus' or 'China virus' has the potential to create and perpetuate stigma" (Budhwani \& Sun, 2020, p. 1). This derogatory and stigmatising power of language has been extensively studied by, among others, metaphor scholars. Conceptual metaphor in general, and dehumanising metaphors in particular serve the purpose of denigrating and ostracising certain groups of people or individuals (Musolff, 2007, 2015; Prażmo \& Augustyn, 2020). Linguists are thus, indubitably, well aware of the potential deleterious effect that naming of the virus in an ethnically-loaded way may create. In language, though, there is always room for multiple interpretations of words and expressions, as they carry different semantic potentials. Therefore, in this paper we scrutinise the actual uses of Chinese virus, Wuhan virus, and Asian virus used in reference to COVID-19 found in English-language Internet discourse. Based on our analysis, we claim that they possess a number of meaning potentials that can be roughly grouped into several semantic nodes, which vary significantly in the activated levels of the (i) specificity, (ii) subjectivity and (iii) axiological markedness of the construed interpretation.

Our study is maintained within the theoretical framework of cognitive semantics in general, and a combination of two theories: Norén and Linell's (2007) theory of meaning potentials and Fauconnier and Turner's $(2002,2003)$ conceptual integration theory further elaborated by, among others, Brandt and Brandt (2005) and Oakley and Coulson (2008), in particular. By applying the theory of meaning potentials we ground our study within the situated sense-making approach to semantics. This view, we claim, is the only one which convincingly explains the dynamic nature of meaning and accounts for the way meaning 
changes across different contexts and situations. Conceptual integration theory, in turn, provides the multi-step mechanism which lays the foundations of meaning elaboration. It also serves as an explicatory mechanism for meaning elaboration and the existence of multiple interpretations of an expression depending on which parts of its semantic profile are highlighted in a given discourse situation. The application of both of these theories creates a coherent and comprehensive theoretical machinery for analysing subtleties of meaning otherwise invisible.

\title{
THEORETICAL FRAMEWORK
}

\section{MEANING POTENTIALS}

The notion of meaning potentials (Allwood \& Gärdenfors, 1999; Norén \& Linell, 2007; Matthiessen, 2009), or semantic potentials, belongs to lexical semantics located within the frame of situated sense-making. According to this approach meanings are not inherent to and fixed upon forms, but "lexical meanings often change diachronically, and synchronic studies of conversation show that a dynamic sense-making of utterances takes place in local situated contexts" (Norén \& Linell, 2007, p. 387).

Aijmer (2013) supports the view that the concept of meaning potentials can cope with meanings of lexical items which do not have clearly defined boundaries (i.e. are underspecified) and only develop their meanings in situated use. Also, the existence of multiple meaning potentials whose interpretations may at times be mutually contradictory, helps account for the semantic ambiguity intrinsically present in words and expressions (Smirnova \& Tolochin, 2018).

Norén and Linell (2007) stress the importance of context in meaning interpretation. They propose:

\footnotetext{
that the semantics of words or grammatical constructions are not just abstract schemas, to be filled in by pragmatic enrichment in situated uses. Nor are words associated with simple lists of different usages. Instead, we propose a theory of meaning potentials. The basic assumptions of such a theory are that linguistic resources provide language users with semantic resources to understand, say and mean specific things in particular usage events, and that this always involves an interplay with contextual factors. (Norén \& Linell, 2007, p. 387)
}

The context in which lexical items occur can be understood broadly as socio-cultural or, more narrowly, as situational context, but also - and this bears special relevance to this paper - as the immediate linguistic context, or co-text, in which lexical items occur:

\begin{abstract}
A theory of meaning potentials assumes that parts of a word's meaning are evoked, activated or materialised, foregrounded or backgrounded, in different ways in the different types of contexts, in which it is exploited. Thus, there is no fixed and static semantic structure which is always activated in its entirety every time a specific linguistic resource, be it a word or a grammatical construction, is used. (Norén \& Linell, 2007, p. 390)
\end{abstract}

The importance of context as well as the whole conversational frame including the speaker and the hearer together with their background knowledge, cannot be overestimated. Meanings are underspecified and "therefore always supplemented by pragmatic enrichment, when expressions are exploited in situated use" (Norén and Linell 2007, 388). Thus, "semantic entries involve some considerable (but possibly varying) amount of context-related information" (Norén and Linell 2007, 388). This accounts for multiple interpretations of a single expression in different contexts and suggests why it is advisable to select the wording cautiously if multiple interpretations are available. It also justifies a certain prescriptivism in the use of forms whose associations with particular meanings are already strong enough to 
distort the intended meaning (especially if the hearer/reader lacks adequate knowledge to arrive at the correct interpretation or if the context itself is ambiguous). Repeated context and co-text strengthen the prototypical meaning associated with a particular linguistic item or expression as well as other, even non-prototypical meanings if their usage is frequent enough within a condensed time frame in a given context. Some "meaning potentials" are overshadowed by the more prominent ones, and meaning potential itself can be defined as "the set of properties which together with contextual factors, including features of the linguistic co-text as well as various situational conditions, make possible all the usages and interpretations of the word or construction that language users find reasonably correct, or plainly reasonable in the actual situation of use" (Norén and Linell 2007, 389). Hence, on the one hand, there are some stable potentialities residing in words, but, on the other hand, this repertoire is changeable and dependent on the context of use. Being aware of different meaning potentials of words and expressions forms part of the knowledge of language and is indispensable for using a language in a proficient and mindful way. In order to conduct a comprehensive analysis of the dynamic meaning construal, all of these factors (socio-cultural, situational, and linguistic context, as well as the speaker's and hearer's background knowledge) must be taken into account. To recap,

\begin{abstract}
a comprehensive linguistic analysis of meaning construction should take into account the contextual factors in the entirety of their different aspects, including both the purely linguistic as well as the extralinguistic contextual circumstances (i.e. those pertaining to cultural, social or any other specific knowledge) at all levels of their specificity. Second, since each linguistic expression constitutes a situated act of communication between the interlocutors, all aspects of the relation holding between them, such as situational and interpersonal settings as well as physical and subjective experience involved in the construal of a particular linguistic scene, may exert substantial influence on the meaning construction process and thus they are potentially of great importance.
\end{abstract}

(Augustyn, 2017, p. 195)

The concept of meaning potentials, thus, assumes not only a dynamic, but in a way an interactive process of meaning construal as readers/listeners are not passive, they interact with the text, interpret it, etc. This approach allows for a great deal of subjectivity too, as the representation of meaning is heavily dependent on readers' background knowledge, assumptions and expectations. Different contexts strengthen the likelihood of activating certain potentials surpassing, at the same time, others.

Before proceeding to the following section, it is also worth investigating the question of deliberateness. Are certain words and expressions used in a calculated and deliberate way so as to facilitate the activation of desired meaning potentials? Does underspecification of meaning allow for creating deliberately misinformative, or even offensive, racist, and xenophobic possibilities of interpretation of the seemingly harmless lexemes? It seems that there exists such a possibility. Prażmo (2017) investigates the use of Polish concentration camps and similar expressions which are ample in WW2-related discourse. Their function is twofold. On the one hand, such expressions serve as mental shortcuts used by the speaker who assumes a certain level of historical knowledge on the part of the hearer and relies on the correct activation of a proper meaning potential residing in the word Polish (Polish concentration camp, i.e. a camp located on the territory of Poland, rather than, for instance, organised by the Polish). On the other hand, using an expression such as Polish concentration camp may have a deliberately misinformative purpose and aim to cast historical blame for creating concentration camps on Poles. This aim is achieved if the hearer lacks adequate level of historical knowledge and relies on the purely linguistic interpretation of the word Polish. The most likely semantic potential to be activated is that corresponding to the prototypical meaning which, in turn, is based on the reader's experience. Similarly, in this paper, we attempt to shed light on the meaning potentials residing in Chinese virus and similar expressions which have 
been proliferating in the English-language Internet discourse since the emergence of the new coronavirus in 2019 and the outbreak of the COVID-19 pandemic.

\section{CONCEPTUAL INTEGRATION THEORY}

Different meaning potentials of words and expressions are activated not only in different sociocultural contexts, but also in the more immediate linguistic contexts, i.e. as parts of structures and compounds. Compounds are based on conceptual juxtaposition of two or more elements and their meanings are more complex than what could be predicted from sum of their constituent parts. These meanings, apart from semantic cargoes directly derivable from individual parts of a compound, are enriched by non-derivable information which emerges in a given context. This emergence can be accounted for by means of the Conceptual Integration Theory (CIT). The theory draws upon the concept of mental spaces (Fauconnier, 1985), defined as conceptual packets of information which are activated on-line in a discourse. It was proposed by Fauconnier and Turner $(2002,2003)$ and further developed and refined by, most notably, Brandt and Brandt (2005), and Oakley and Coulson (2008). CIT postulates the dynamic and emergent nature of meaning creation, and thus can be successfully applied to the analysis of novel expressions, whether completely neologic in nature or rather neosemantic, such as the examined compounds.

In the ensuing analysis we take recourse to a modified framework of conceptual integration (see Fig. 1), which we develop on the basis of the contextual blending models envisaged by Brandt and Brandt, and Oakley and Coulson (Brandt \& Brandt, 2005; Oakley \& Coulson, 2008; Brandt, 2012). The two approaches differ slightly in the adopted nomenclature but both account for the pragmatic embedding of the blending process in the discourse and the communicative relevance, which were largely neglected in the original CIT proposed first by Fauconnier and Turner (2002). The revised conceptual integration model uses six spaces, which we want to briefly discuss below (cf. this account, which tries to combine the two aforementioned approaches into one, with the actual models described by Brand \& Brandt 2005: 224-240 and Oakley \& Coulson 2008: 30-31).

The conceptual integration process starts with a Discourse Space, i.e. the space where the actual cognitive work takes place. It grounds all further space building processes and may be understood as a space representing the discourse participants' acts of engaging in discourse and construing meaning. It thus sets a subjective stage for the whole meaning construction process, which is constrained by the human phenomenological world and situational context. Other mental spaces operate in line with the Discourse Space. The Reference Space pertains to the discourse topic active at the moment of linguistic communication, it relates to actuality (it may be built from explicit or contextual cues). The Presentation Space is a predicating space and can be more figurative, though it usually also contains some schematic structure. In both models the inputs tend to be functionally distinct and thus asymmetrical.

The Blended Space involves the integration of selected elements from the two input spaces (Reference and Presentation). It functions as a simulation space where the conceptualiser can mentally access different elements from the inputs and think about them in a particular way, trying out different possible scenarios by different framings of the selected elements from the inputs. Blended spaces "are momentary fictions that yield lasting inferences" (Brandt, 2005, p. 227). However, the mental simulations at this stage are still rudimentary and there is still no emergent meaning. In fact, different framing scenarios may be tried out during this mental simulation phase, but the framing of the inputs is contextually motivated. The process of framing the inputs itself can be described as "elaboration loop [...] because this framing process is open-ended and reciprocal. That is, online adjustments or alterations in the 
course of a mental simulation can happen (since it is an online dynamic process), and alterations in one space can influence the framing of the other spaces" (Brandt \& Brandt, 2005, p. 232).

The structure that the inputs have in common, the shared structure, is captured in this model by Relevance Space, which specifies what is situationally relevant, depends on the goal and purpose of the discourse participants and is contextually sensitive. All the background knowledge contributes to the framing of the blend (via different cognitive operations such as profiling, schema activation etc.), e.g. the Relevance Space contains knowledge of the given issue possessed by the discourse participant, it provides the relevant thought content for the framing of the blend and the emergence of reasonable inferences at the pragmatic level. Finally, the Elaboration Space is the space drawing on the active and available blend, enabling creative elaboration of the blend depending on the pragmatic relevance. Put differently, it is properly framed blend (with the meaning emerging only in the interpretive process structured by the Relevance Space). The meaning which is produced in the blend is the result of the synergistic forces and well as contextual demands, which stresses the importance of the pragmatic nature of meaning creation. The contextual models of conceptual integration highlight the (un)surprisingly simple pragmatic condition for successful meaning-making: "to understand what the speaker means is to 'get' the relevance right" (Brandt \& Brandt, 2005, pp. 241-242).

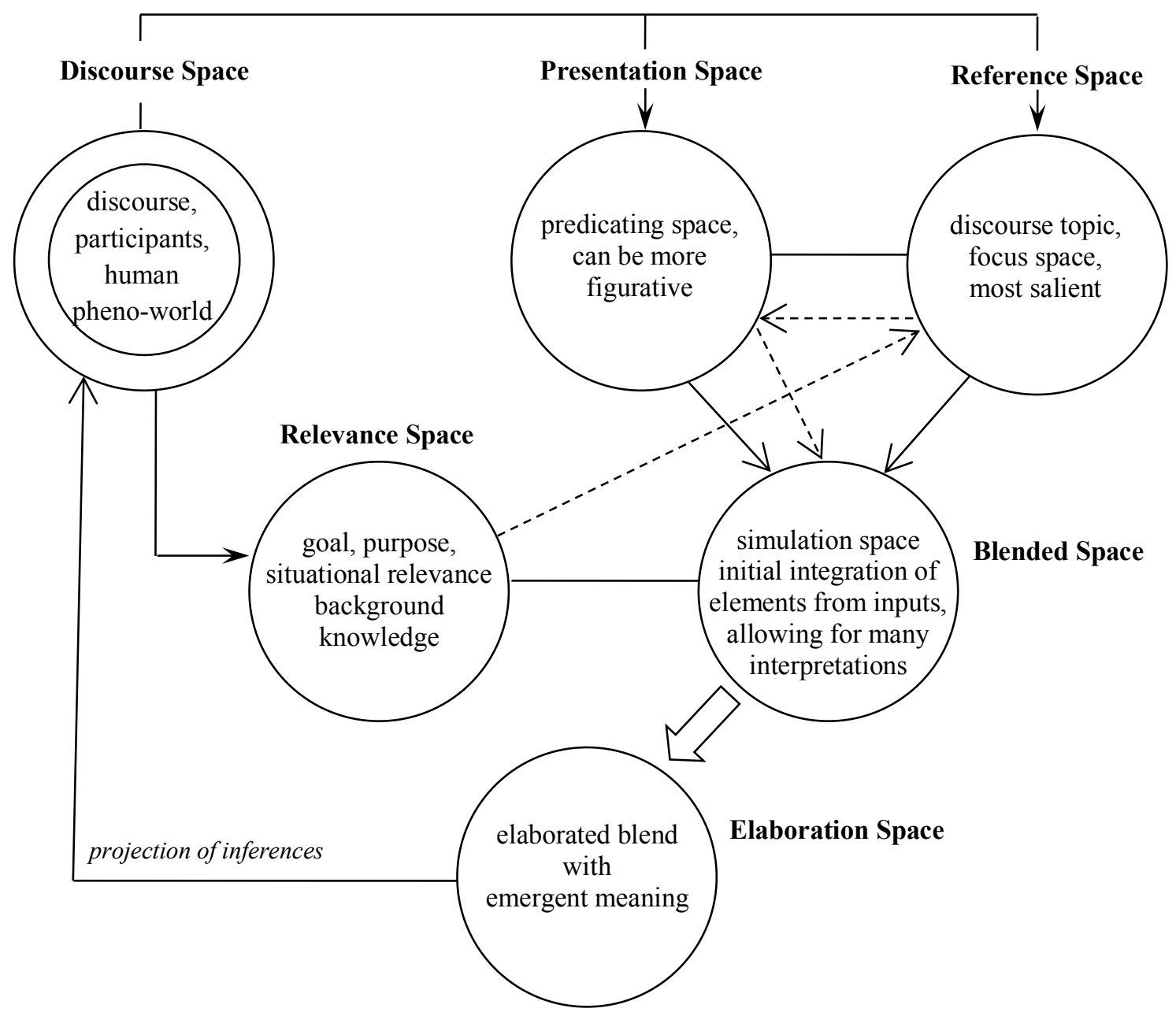

FIGURE 1. Extended conceptual integration model (based on Brandt \& Brandt, 2005; Oakley \& Coulson, 2008) 
Indeed, relevance plays a crucial role in both the coining (production) of novel lexical items and the interpretation of their meanings. This is line with the principles of relevance proposed by Sperber and Wilson:

Cognitive principle of relevance

Human cognition tends to be geared to the maximisation of relevance.

Communicative principle of relevance

Every aspect of ostensive/overt communication conveys a presumption of its own optimal relevance.

(Sperber \& Wilson, 1995, pp. 260-272).

Sperber and Wilson further observe that

This communicative principle of relevance provides the motivation for the comprehension procedure, which is automatically applied to the online processing of attended verbal inputs. The hearer takes the conceptual structure constructed by linguistic decoding; following a path of least effort, he enriches this at explicit level and complements it at the implicit level, until the resulting interpretation meets his expectation of relevance; at which point, he stops. (Wilson \& Sperber, 2012, p. 39)

Coincidentally, their description of the comprehension mechanism is congruent with the recursive process of conceptual integration, in particular at the stage of blend creation, where a particular conceptualiser/discourse participant creates potentially infinite cognitive simulations trying to arrive at the meaning of an utterance/expression that satisfies his/her expectation of relevance.

It is also important to emphasise that in this revised CIT model the process of blending (and interpreting new meanings) is not closed and finite, but rather an open-ended, recursive and iterative operation as the inferences that emerged in the elaborated blend may be fed by the conceptualiser back to the ongoing discourse and become subject of further integration processes (Oakley \& Coulson, 2008, p. 31). We argue that this is especially the case with salient neo-concepts (entirely new concepts or new senses linked to a specific linguistic form), which circulate in the discourse with increased frequency for a certain period of time, and are subject to different modification until a particular form-sense pairing becomes accepted by a given speech community in a relatively stable, conventional meaning. The practical working of this model combined with the idea of meaning potentials and their usefulness in meaning interpretation will be shown in the ensuing analytical part.

\section{METHODOLOGY}

\section{SOCIOLINGUISTIC BACKGROUND}

Before we proceed with the proper cognitive semantic analysis of the potential different meanings behind the examined expressions, a brief contextual outline is pertinent here.

First, it must be emphasised that as the threat of the novel coronavirus was identified by WHO, in January it recommended the name "2019 novel coronavirus" (2019-nCov) as the provisional name for the virus, which is in line with WHO 2015 guidelines stipulated in the document "World Health Organization Best Practices for the Naming of New Human Infectious Diseases", which were specifically laid out

[...] with the aim to minimize unnecessary negative impact of disease names on trade, travel, tourism or animal welfare, and avoid causing offence to any cultural, social, national, regional, professional or ethnic groups [emphasis added].

Given the increasingly rapid and global communication through social media and other electronic means, it is important that an appropriate disease name is assigned by those who first report a new 
human disease. WHO strongly encourage scientists, national authorities, the national and international media and other stakeholders to follow the best practices set out in this document when naming a human disease. If an inappropriate name is released or used or if a disease remains unnamed, WHO, the agency responsible for global public health events, may issue an interim name for the diseases and recommend its use, so that inappropriate names do not become established. (WHO, May 2015, https://www.who.int/topics/infectious diseases/naming-new-diseases/en/)

Despite this action and a clear recommendation issued by WHO, other names for the virus soon started appearing in the English-speaking media, derived from ethnonyms: Wuhan virus, Chinese virus, Asian virus. Given the cascading information flow and viral news spread in contemporary media, it is difficult to pinpoint the exact time and source of first such uses to refer to SARS-CoV2 (Table 1 presents general statistics on the frequency of selected phrases based on Google search engine results). However, their conscious and deliberate use by highranking politicians, in particular US President Donald J. Trump, certainly contributed significantly to their higher circulation in traditional and social media, which directly influences the activation of concrete semantic potentials (esp. those carrying an axiological charge) while eclipsing the other, more conventional semantic portions of those expressions.

TABLE 1. Google search engine results for examined expressions, for entries marked with * see the description below

\begin{tabular}{|c|c|c|c|c|c|c|c|c|}
\hline phrase & $\begin{array}{l}\text { Nov } \\
2019\end{array}$ & $\begin{array}{c}\text { Dec } \\
2019\end{array}$ & $\begin{array}{c}\text { Jan } \\
2020\end{array}$ & $\begin{array}{c}\text { Feb } \\
2020\end{array}$ & $\begin{array}{l}\text { Mar } \\
2020\end{array}$ & $\begin{array}{l}\text { Apr } \\
2020\end{array}$ & $\begin{array}{l}\text { May } \\
2020\end{array}$ & $\begin{array}{l}\text { June } \\
2020\end{array}$ \\
\hline Chinese virus & $23 *$ & $36^{*}$ & $5,7 k^{*}$ & $8,1 k$ & $75,5 k$ & $90,4 k$ & $19,1 k$ & $12,4 k$ \\
\hline Wuhan virus & $21 *$ & $3 *$ & $21,3 k^{*}$ & $42,9 k$ & $90,2 k$ & $84,3 \mathrm{k}$ & $29,8 k$ & $17 k$ \\
\hline Chinese virus + Wuhan virus & $0 *$ & $0 *$ & $455^{*}$ & $1,1 k$ & $10,2 k$ & $9,9 k$ & $2 k$ & $1,1 k$ \\
\hline Asian virus & $7 *$ & $1 *$ & $31 *$ & 317 & 715 & 776 & 261 & 97 \\
\hline
\end{tabular}

The Google search results were obtained on 27 July 2020. Advanced search method was used, with custom range time limitation of results for particular months. No geographical constraints were imposed on the search except for the English language condition. The search was conducted using the exact phrase recognition (the phrase put in quotes). For the Chinese virus + Wuhan virus, we considered only sources containing both respective phrases simultaneously; $k$ stands for thousand results (rounded off to one decimal place).

However, there are some limitations to the actual usability of the obtained results. For instance, certain webpages use dynamic elements in their source coding, which results in older sites (e.g. pre-December 2019 but also those in 2020) containing elements with the examined phrase originating from later periods. This results in the reduplication of certain search results or produces false results (results coming from a later period).

In order to partially mitigate this effect, for the first two examined months (November, December) we excluded searches containing words "COVID", "coronavirus" and "2020" as these tags produced a substantial number of false results (counted in thousands), whereas for January we excluded searches with "COVID" as this term was introduced by WHO only towards the end of that month (the search results for these months are marked with *). It cannot be excluded that the search results from the ensuing months bear the same risk of being overrepresented, however with the current working of the search engine it is difficult to suggest further exclusion criteria.

Given the constraints described above, we acknowledge that these results cannot be seen as (truly) statistically accurate, but in our view, they help put the whole analysis into perspective by adding important contextual hints (this may be compared to average exposure of language speakers to some language input, on the basis of which they later intuitively construe meanings). 
First, it can be assumed that the results for the examined expressions from late 2019 were rather occasional/accidental. The instances of the expression Asian virus are actually very infrequent (compared to others analysed here).

The most common expressions are Chinese virus and Wuhan virus. They started to be used at the onset of the COVID-19 outbreak, but their frequency of use peaked in March and April, which coincides with the enormous media hype over the fact that US President Trump used the term Chinese virus during his official press briefing on 18 March 2020 (cf. https://www.nytimes.com/2020/03/18/us/politics/china-virus.html). In fact, he had repeatedly resorted to using this phrase as early as in January, but it caught media attention only later in March. Interestingly, this time frame coincides with the worsening of US-China relations in the area of economic cooperation - the process which had started before the COVID-19 outbreak.

Considering the effect of the media hype given to Chinese virus by mainstream news media, it is also easy to neglect the fact, which the statistics above - being imperfect as they might be - easily bear out, that the expression Wuhan virus has been the most frequent from the very start of the coronavirus outbreak. It was matched by Chinese virus only in the period March-April for the reasons adduced above. One explanation of this may be the fact that the term Wuhan virus has been much more frequently used in scientific reports (or more generally in non-mainstream news media) and thus its usage in the examined period is more naturally distributed as compared with Chinese virus, although the latter certainly additionally increased the frequency of use of the former, which is also reflected in the number of sources using both terms simultaneously in the peak period of March and April (incidentally, these are mainly sources criticising the potential racism inherent in both terms). Quite naturally, the frequency of use of both terms (Wuhan virus and Chinese virus) declined sharply in May as other (social) issues hit the public debate in many countries (such as the resurgence of Black Lives Matter movement in the USA after severe cases of racial discrimination and police killings of Black people in the USA).

\section{CORPUS DATA}

The present paper is primarily conceived of as a qualitative analysis of selected contexts in which phrases Wuhan virus, Chinese virus, and Asian virus occur. Although it has not meant to be a quantitative corpus-based study, the examples analysed below are extracted from the NOW Corpus (News on the Web - https://www.english-corpora.org/now/) which, at the time of data compilation, contains 10.7 billion words from web-based magazines and newspapers. The corpus, developed by Mark Davies at Brigham Young University, contains data from 2010 onwards and is updated on a daily basis with the use of automated scripts, which guarantees an up-to-date database of news texts. The corpus was used to extract tokens of three expressions: Asian virus, Chinese virus, and Wuhan virus. The original sources containing these were subsequently searched manually in order to select original contexts in which the three expressions appeared (with the exclusion of the articles which, among others, explicitly comment on the use of the term Chinese virus etc.). The corpus also enables for the selection based on the chronology of publication of given texts, and thus this information is also included at the top of each quoted example.

Additionally, our analysis includes a brief examination of search results for the examined phrases produced by the Google search engine, adduced here as a larger-scale representation of certain discursive trends over the last few months (for a more detailed discussion, see the section above). 


\section{ANALYSIS}

\section{COGNITIVE SEMANTIC ANALYSIS}

Below, we present an assorted selection of excerpts which include the phrases Chinese virus, Wuhan virus and Asian virus, and offer a tentative analysis of the most likely meaning potentials activated in each context. For space constraints, we can discuss only just a few examples, but these represent the most salient and common interpretations of the analysed phrases found in the corpus. Particular emphasis is put on capturing and explaining the cognitive mechanisms responsible for such (possible) interpretations. The order of the examples adduced below reflects the gradual accretion of semantic potentials and further extensions of the emergent meanings behind the examined expressions, i.e. from the more prototypical meanings to increasingly more complex conceptual blends (this complexity grows with the increasing level of subjective argumentation and figurativity of expressions used by text authors).

1) 16 January 2020

Japan confirms case of new Chinese virus, spread is 'concerning'

TOKYO (Reuters) - Japan has confirmed its first case of infection from a newly-identified coronavirus that has killed one person and infected at least 40 more in China, as well as prompting a travel alert from the U.S. State Department.

https://uk.reuters.com/article/us-china-health-pneumonia-japan/japan-confirms-first-case-ofinfection-with-new-china-coronavirus-idUKKBN1ZF02Z?feedType $=$ RSS\&feedName $=$ health News (accessed on 30 July 2020)

This excerpt from an article published by Reuters in mid-January 2020 clearly uses the term Chinese virus to mark the place of the virus' origin and its subsequent spread from China to Japan. This 'geographical' meaning has no evaluative component to it. Its main function is to provide objective and straightforward information without attempting to cast blame or assign any axiological load to China or the Chinese. This is an example of a simple blend creation, merging the basic semantic potentials of Chinese (a state, a specific geographical area) and virus (an infectious agent that may cause a disease).

2) 21 January 2020

Stop the Wuhan virus

Vigilance, preparedness, speed, transparency and global coordination are now crucial to stopping a new infectious disease from becoming a global emergency. https://www.nature.com/articles/d41586-020-00153-x (accessed on 27 July 2020)

In excerpt (2), similarly to excerpt (1), the geographical origin (although here with greater specificity by profiling a single city in China) of the virus is used as a means to create an ad hoc, preliminary name to the yet (as in January 2020) nameless new virus This article explicitly mentions the fact that the new virus lacks a formal name and provides a tentative name used in January, i.e. 2019-nCOV. Thus, the term Wuhan virus is used in an innocuous way and is meant to provide accurate information about the place of origin of the virus and not to stigmatise the city of Wuhan in any way.

3) 24 January 2020

Something Far Deadlier Than The Wuhan Virus Lurks Near You

There's a deadly virus spreading from state to state. It preys on the most vulnerable, striking the sick and the old without mercy. In just the past few months, it has claimed the lives of at 
least 39 children. The virus is influenza, and it poses a far greater threat to Americans than the coronavirus from China that has made headlines around the world.

https://khn.org/news/flu-far-deadlier-than-wuhan-virus/ (accessed on 27 July 2020)

This excerpt also activates primarily the geographical meaning of the Wuhan virus, yet the metaphorical framing on which it is built and additionally introduced to this segment of discourse as part of the Relevance Space is also worth mentioning. The Wuhan virus is juxtaposed here with the influenza virus which is metaphorically described as a dangerous animal "lurking", "praying on the most vulnerable", "striking the sick and the old without mercy". This predatory frame is extended into all the other viruses, including the Wuhan virus, and thus can lead, even if not intentionally, to assigning negative axiological evaluation to Wuhan itself. The "predatory" meaning is not explicitly present neither in the word virus, nor in any expressions it forms, but the VIRUS IS A DANGEROUS ANIMAL metaphor is very common, and thus can be exceptionally influential (see e.g. Liebert, 1997).

4) 21 January 2020

Yuan weakens, safe havens gain on Chinese virus concerns

NEW YORK (Reuters) - China's yuan tumbled on Tuesday and the safe-haven Japanese yen rallied as the spread of a pneumonia-like virus in China dampened risk appetite. [...] Global stocks fell as the outbreak rekindled memories of the severe acute respiratory syndrome (SARS) in 2002-2003, another coronavirus which broke out in China and killed nearly 800 people in a global pandemic.

https://www.reuters.com/article/uk-global-forex/yuan-weakens-safe-havens-gain-on-chinesevirus-concerns-idUSKBN1ZK022 (accessed on 30 July 2020)

In excerpt (4), apart from the geographical meaning marking the origin of the virus (the meaning which seems to be present in the great majority of all studied uses), there seems to be an underlying evaluative component. China seems to be accused of threatening the value of the Japanese yen and destabilising global currency markets and the economic situation in general. This is exemplified by the lexical opposition of positively valued expressions such as "safehaven yen" (Japanese economy) and the negative imagery evoked by "yuan tumbles"/“yuan weakens" (Chinese economy), and further strengthened by referring to the previous outbreak of another virus which also originated in China. This dichotomy is structured alongside the UP and DOWN axis of the UP-DOWN orientational metaphor where UP canonically represents all the good, positive and desirable values and states, whereas DOWN represents the negative and undesirable values and states. This, however, is only a tentative interpretation of the evaluative element underlying the structure of the excerpt. Any accusations and grievances, if present at all, are only implied and there is no explicit blame-casting. At the same time, juxtaposing Chinese virus with "concerns" in the heading of the article which deals with negative economic consequences of the situation brought about by the virus which has emerged in China, opens up the possibility for such negative interpretation, thus creating a new meaning potential which can be then readily activated elsewhere.

5) 26 February 2020

Dow Jones plummets another 880 points - Soooo can we start panicking about the Wuhan virus yet or is that still racist?(...) This isn't a fucking Identity Politics issue you woke clowns, this has always been a public health emergency and economic meltdown moment, we didn't need Chinese repression to hide this, we just needed virtue signalling woke activists to censor it. (...) China was always lying about the enormity of this novel virus and we must urgently move to protect ourselves now. As TDB pointed out when this first emerged, Wuhan Virus ain't nothin to fuck with. 
https://thedailyblog.co.nz/2020/02/26/dow-jones-plummets-another-877-points-soooo-canwe-start-panicking-about-the-wuhan-virus-yet-or-is-that-still-racist/ (accessed on 30 July 2020)

In this excerpt there is a simultaneous activation of the geographical and pejorative meaning, strengthened by the particularly informal style and low register of the text. The author of this article is mainly concerned about the state of the global economy and the inevitable recession that would result from the pandemic. There is no direct blaming China for the virus itself, but rather for all the economic consequences that its global spread would cause. According to the author, China was lying about the severity of the situation and this fact only exacerbated the already difficult situation. The author does not seem to blame China for creating, deliberately or not, the virus, but for rejecting that it happened. Nonetheless, this negative, accusatory attitude permeates the whole text and can easily be projected onto the expression Wuhan virus giving it very negative overtones. This might be additionally accounted for by the activation in the Relevance Space of some force image schemas supporting the conceptualisation of this scene, in particular BLOCKAGE ("China was always lying", "Chinese repression hiding it"), DIVERSION ("is calling it Wuhan virus still racist?") and asking for ENABLEMENT ("can we start panicking") - all these help create a vivid action-oriented narrative with a number of semantic elements having clearly negative connotations (inter alia, "meltdown", "censor", "panic"). Additionally, the author puts Wuhan virus into the centre/profile of the scene - with other aspects being on the periphery thus setting a scene for a potential conflict (CENTRE-PERIPHERY image schema). Though ultimately it is down to the reader's ability to subconsciously access these image schemas, we argue that the author's choice of lexical means clearly facilitates it.

6) 17 March 2020

The Quislings can, no doubt, explain all this away, probably in terms of decrying Western ignorance and prejudice but it's much harder to explain away the bald fact that over 3,000 people have died and way over 80,000 people have been infected by the virus in China. I mean the Wuhan virus, which we're supposed to call the Covid-19 virus because it's so impolite to be point fingers and assign blame.

Only the most bigoted of commentators would be so crude as to point out that this is the second time (the first being SARS) in the space of two decades when China has been the source of a fast-spreading and deadly virus. In both instances, the epidemic arose from contamination in the food chain.

https://hongkongfp.com/2020/03/17/hero-coronavirus-crisis-china-according-statepropaganda/ (accessed on 30 July 2020)

Here, in a like manner to the previous excerpt, the geographical meaning is conflated with accusatory undertones. The author ostensively uses the term Wuhan virus and explains his choice of the term referring to COVID-19 death and infection rates from China. The fact that numerous people were infected and died from the disease is reasonable enough to use the Wuhan virus as a straightforward way to describe the virus. The accusation the author presents leaves little room for alternative interpretation. They link the emergence of the virus to reckless food production practices as "the epidemic arose from contamination in the food chain". Also, they juxtapose the new coronavirus with the previous emergence of SARS stating that it is the second time "in the space of two decades when China has been the source of a fast-spreading and deadly virus".

7) 15 May 2020

While the world struggles to combat the deadly pandemic spread by the Chinese Wuhan virus named as Covid 19 and popularly being referred to as coronavirus, the dragon nation believed to be the originator and spreader of the deadly virus is busy working out its options to combat 
the international pressure and campaign launched against it. The nation which was dreaming to become the world leader is today finding itself pushed to the wall with most nations joining together demanding an international inquiry into how the Wuhan virus emerged out of the laboratory and the deliberate delay in sharing the information about its existence? The international community holds China whole and sole responsible for this and blames it of deliberately delaying the sharing of information that caught the world unawares.

https://www.thenorthlines.com/let-the-dragon-remain-pushed-to-the-wall-2/ (accessed on 30 July 2020)

This excerpt presents an intentionally polarising style of writing with strong political ideology clearly underlying the text. The double metonymic reference Chinese Wuhan virus was probably meant to reinforce the accusations cast against the Chinese. Thus, aside from clearly stating the geographical origin of the virus, the author demonstrates the belief that the virus was created and spread deliberately by the Chinese. The author uses a nickname "the dragon nation" which may serve to activate the danger frame and add aggressive, malevolent component to the whole conceptualisation. China is thus represented not only metonymically (STATE FOR THE GOVERNMENT) but also metaphorically (STATE IS A PERSON, STATE IS AN ANIMAL, CHINA IS A DRAGON). China is "believed to be the originator and spreader of the deadly virus". The use of agentive suffixes -or and -er in "originator" and "spreader" further strengthens intentionality of the China's actions. To make matters worse, there was a "deliberate delay in sharing the information" about the virus after it had "emerged out of the laboratory". All of these accusatory tones permeate into the used expressions and extend the meaning potentials of Wuhan virus beyond the neutral geographical ones. It is effectively achieved by using a great number of elaborate conceptual operations (metonymy, double metonymy, metaphor, anthropomorphisation, animalisation). In addition, it cannot be excluded that a broader political context can partially inform this intentionally polarising style of writing, as this excerpt comes from an Indian newspaper from the region of Jammu and Kashmir, which is close to the Chinese border - an area marked by the Sino-Indian border conflict since the mid- $20^{\text {th }}$ century.

8) 4 May 2020

The Covid-19 pandemic has aggravated the already sinking US-China relationship attributed to the two countries' trade, technology and geopolitical wars. The US is increasingly blaming China for the spread of the coronavirus, the damage it has done to the economy and the large number of deaths. [...]. With regard to China with holding information from the US, the charge is highly debatable. [...] In any event, it seemed that whether or not the information was delayed, it did not really matter, because Trump (and perhaps other Western leaders as well) brushed China's warning off, saying that the coronavirus was no more dangerous than the common flu and would blow over soon. So Trump and other Western leaders not only did nothing, but tried to convince themselves that Covid-19 was an "Asian virus" and thus a problem that would not spread to the West.

https://asiatimes.com/2020/05/us-china-blame-game-a-lose-lose-proposition/ (accessed on 9 August 2020)

In this excerpt, a number of intermingled meaning potentials seems to be at play. First, there is a geographical indication linking the origin of SARS-CoV-2 virus to the Asian world. Second, there seems to be an accusatory and blame-casting component present too (this was already signalled in the title of the article: "US-China blame game a lose-lose proposition"). The Western leaders accuse the Chinese government of withholding information (or at least delaying sharing the information) about the emergence of the new virus from the rest of the world. As a result, no timely measures could be undertaken in order to curb further spread of the virus and the Western countries could not take proper protective measures in advance. 
Finally, the author of the article overturns this argument and claims that Western leaders - with or without receiving information about the virus in due time - were not willing to take any special measures against it, as they believe that it was an "Asian virus" i.e. the virus which was dangerous only to the Asian population and for this reason it would not spread to the West. The mutual accusatory attitude of both the USA and China towards each other permeates the whole text and is projected onto the expression Asian virus giving it a (slightly) negative overtone. This is strengthened through the activation in the Relevance Space of the COUNTERFORCE image schema ("US-China blame game") which underpins the conceptualisation of this scene by emphasising the existing tensions between the West and Asia, and framing the dispute from the perspective of the "trade, technology and geopolitical wars" between the two main players. Excerpt (8) constitutes one of few examples of the use of Asian virus which was greatly outnumbered by Wuhan virus and Chinese virus in the corpus (frequencies for each of the analysed expressions in the NOW corpus as of 9 August 2020: Wuhan virus 2220, Chinese virus 1620 , Asian virus 21).

\section{FINDINGS}

As we have tried to show, the interpretation of the abovementioned examples depends on a number of factors such as contextual cues, the conceptualiser's background knowledge, assumptions and expectations as well as their knowledge about the text author's intention. In terms of the CIT approach and the notion of meaning potentials advocated here, all these factors (variables) derive from the Discourse Space and the most important parts of these, directly relevant to the interpretation of a given expression, are captured in the Relevance Space. Depending on the interplay of these factors, different meaning potentials inherently present at any given linguistic expression can be activated. These meaning potentials can be of different kind:

(a) they can be accessed directly from separate input spaces as ingredients of a dynamic composition of senses (the first stage of blend creation);

(b) they can be accessed additionally as part of a particular discourse framing or other conventional cognitive structures such as metaphors or image schemas in the process of completion (the second stage of blend creation);

(c) new meaning potentials are generated in the process of meaning elaboration, which are subsequently fed back to the discourse space (the final products of conceptual blending, a material for potential further blending). 


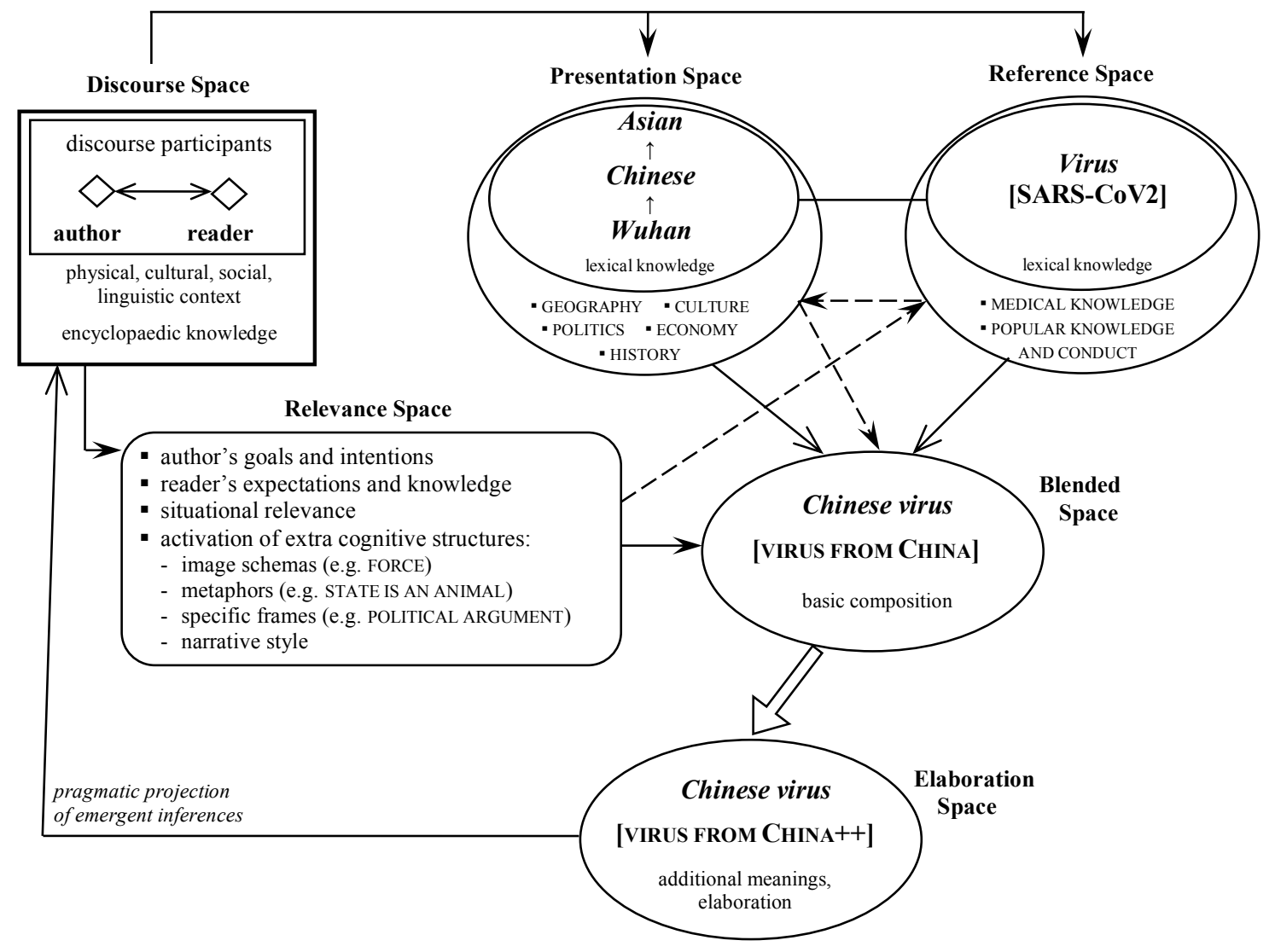

FIGURE 2. CIT model of meaning interpretation of Chinese virus

Some of those meaning potentials may be first activated automatically (a), sometimes requiring a bit more cognitive effort (b) and then updated as the new information unravels in the course of reading (c). They may be activated individually, or clustered together creating more complex meanings. Some usages, though, are clearly intentional and meant to channel the reader's interpretation towards a very salient meaning potential. Such an intentional naming has led to 'politicising' the virus and consequently to creating negative attitudes towards people of Chinese, and then even - by category extension - Asian descent. For a schematic representation of meaning construction for Chinese virus, which serves as a template also for the meaning interpretation of the other two expressions, see Fig. 2.

Based on the discussed examples we were able to discern the following potential senses for Chinese virus:

(i) virus originating in China (and spreading from there all over the globe) - the most conventional sense, activated on the basis of simple input composition;

(ii) virus affecting only (or primarily) the Chinese - a potential, albeit weak sense relying mostly on simple composition and the reader's broader linguistic knowledge (lexical priming effect);

(iii) virus created in China and spread intentionally by the Chinese (the Chinese government) in order to disrupt the global economy and defeat the (US-style) capitalism in the world a potential sense evoked by the additional, intentional framing of the text by the author in a manner characteristic of (political) arguments, often accompanied by the activation of FORCE image schemas;

(iv) virus created in China and unintentionally spread by the Chinese because they did not manage to handle it efficiently and keep contained in their laboratories - a potential sense 
construed similarly to the previous case, but the underlying text narration tends to be less argumentative, SPATIAL MOTION image schemas (e.g. CONTAINMENT, BLOCKAGE) are more prevalent;

(v) virus whose control is the responsibility of the Chinese and the Chinese government, because it has originated in China - a potential sense that is a further elaboration (mainly through the projection of emergent inferences back to the discourse) of senses (iii)/(iv);

(vi) virus as a metaphorical representation of the Chinese, the Chinese as a virus spreading throughout the globe - a potential sense which is construed similarly to sense (iii), but instead of just adding different discourse frames, the whole text/context is framed very consistently based on a particular (usually cognitively well-entrenched) conceptual metaphor.

Meaning potential (ii), even though present in expressions such as Chinese virus is rather dormant and rarely activated, due to the relatively early verification of the nature of COVID-19. It might have developed first among the Chinese population of Wuhan, but then proved contagious across different ethnic and national groups. Chinese virus interpreted as a virus affecting only the Chinese is similar to expressions such as human virus (a virus that infects only humans), animal virus (a virus that infects non-human animals), or even metaphorical computer virus (a virus that affects computer programs). This interpretation is thus not impossible, but as we had learned early on during the pandemic, it is not the case that Chinese virus affects only the Chinese, nor is it true that Asian virus affects only the Asian population. This 'limiting' interpretation can nonetheless be extended into that of a virus which originally affected only the Chinese, but evolved and mutated in such a way as to be capable of affecting people of other nationalities too (just like animal viruses mutate and spill over to humans very commonly).

As far as (vi) is concerned, we find headlines such as:

9) 26 February 2020

Chinese are not a virus; racism is

https://www.counterfire.org/articles/opinion/20921-chinese-are-not-a-virus-racism-is

(accessed on 3 August 2020)

10) 10 March 2020

'The Chinese are not the virus, we face this epidemic like everyone else' https://evangelicalfocus.com/europe/5168/the-chinese-are-not-the-virus-we-face-thisepidemic-like-everyone-else (accessed on 3 August 2020)

Such headlines are meant as responses to the implied accusations cast against the Chinese, blaming them for the emergence and spread of COVID-19 and metaphorically conceptualising them as the virus itself. This strategy is in line with linguistic strategies meant to denigrate or dehumanise others, which we mentioned above (cf. e.g. dehumanising metaphor).

\section{CONCLUSION}

In this paper we attempted to demonstrate that multiple meanings can be activated at the same time in complex expressions. We examined the three phrases jointly since Chinese virus' meaning potentials are essentially the same as those of Asian virus or Wuhan virus, with these three expressions differing in respect of the scope of predication. Asian virus has the broadest scope of all three, Chinese virus has a slightly narrower scope, whereas Wuhan virus is the narrowest of all. Interestingly, this three-level scope has been broadened even further by the 
use of the expression foreign virus by Donald Trump in his Oval Office address on 11 March 2020 (here, of course, foreign would refer to a very broad and fuzzy category). From a cognitive semantics perspective, both Chinese and Wuhan are the terms that are most natural in terms of naming basic-level category concepts and this is reflected in their huge frequency of use in the examined phrases, as opposed to Asian, which is more general and thus its interpretation would be vaguer. In addition, Wuhan and Chinese in both expressions can metonymically stand for each other (WUHAN FOR CHINA and CHINA FOR WUHAN as instantiations of the PART FOR WHOLE and WHOLE FOR PART metonymies, respectively), hence both expressions are equally frequent.

The actual meaning potentials that are activated in a given case depend, to a great extent, on the author's actual intention behind using a given word or expression, supported by other lexical means and cognitive structures permeating these in the entire text. Thus, the reader's interpretation of a given expression, i.e. the activation of the most likely meaning potential can be guided by the author's aims and the way they are linguistically encoded in the discourse. Additionally, the reader's interpretation is grounded in their background knowledge as well as expectations. At times, there may be no explicit intention behind the use of an expression, apart from cognitive economy, i.e. Chinese virus is shorter than, for instance, $a$ virus which originated in China and subsequently spread to other parts of the world, and thus may serve as a well-established mental and linguistic shortcut. Such uses, although not very precise, are often found in medical, medicine-related or other scientific texts.

The use and 'spread' of the expression Chinese virus and other similar, whether deliberate or unintentional, leads to multiple social implications. Some of these implications are potentially harmful as they tend to perpetuate negative stereotypes held about Asian people in general, and Chinese people in particular. The associations that this (and similar) expression carry may lead to spreading hatred and prejudice against esp. Chinese community (but by extension also all Asian minorities) in the Western countries (esp. in the USA) and may cause an increase in prejudiced, sometimes even racist anti-China sentiments (cf. Croucher, Nguyen, \& Rahmani, 2020, https://www.pbs.org/newshour/health/fears-of-new-virus-trigger-antichina-sentiment-worldwide; accessed on 5 August 2020). These may actually be even observed in China's close Asian neighbours (e.g. "China virus outbreak", "Wuhan virus disaster" in Japan or "Chinese virus go back" in India), which may often facilitate advancing or directly serves certain political agendas (https:/www.indiatoday.in/india/story/bjp-mla-lights-torchchants-chinese-virus-go-back-to-mark-fight-against-covid-19-in-hyderabad-1663725-202004-06; https://theprint.in/world/rename-who-as-chinese-health-organization-japan-slams-unbody-for-giving-into-chinas-spin/393961/;

https://japan-forward.com/why-wuhan-virus-is-the-appropriate-name-for-this-pandemic/; accessed on 5 August 2020).

\section{CORPUS}

NOW corpus (News on the web) https://www.english-corpora.org/now/

\section{REFERENCES}

Aijmer, K. (2013). Understanding Pragmatic Markers: A Variational Pragmatic Approach (1 edition.). Edinburgh: Edinburgh University Press.

AlAfnan, M. A. (2020). COVID 19-The Foreign Virus: Media Bias, Ideology and Dominance in Chinese and American Newspaper Articles. International Journal of Applied Linguistics and English Literature, 9(1), 56-60. 
Allwood, J., \& Gärdenfors, P. (Eds.). (1999). Cognitive Semantics: Meaning and cognition. Amsterdam: John Benjamins Publishing Company.

Augustyn, R. (2017). Deciphering Novel Expressions: A Proposal for an Integrated Cognitive Meaning Construction Analysis. Annales Universitatis Mariae Curie-Skłodowska, sectio FF-Philologiae, 35(2), 192.

Brandt, L. (2012). The Communicative Mind: A Linguistic Exploration of Conceptual Integration and Meaning Construction (Unabridged edition.). Newcastle upon Tyne, UK: Cambridge Scholars Publishing.

Brandt, L., \& Brandt, P. A. (2005). Making sense of a blend: A cognitive-semiotic approach to metaphor. Annual Review of Cognitive Linguistics, 3, 216-249.

Brandt, P. A. (2005). Mental spaces and cognitive semantics: A critical comment. Journal of Pragmatics, Conceptual Blending Theory, 37(10), 1578-1594.

Budhwani, H., \& Sun, R. (2020). Creating COVID-19 Stigma by Referencing the Novel Coronavirus as the "Chinese virus" on Twitter: Quantitative Analysis of Social Media Data. Journal of Medical Internet Research, 22(5). Retrieved July 11, 2020, from https://www.ncbi.nlm.nih.gov/pmc/articles/PMC7205030/

Chen, L., Lyu, H., Yang, T., Wang, Y., \& Luo, J. (2020). In the Eyes of the Beholder: Sentiment and Topic Analyses on Social Media Use of Neutral and Controversial Terms for COVID-19. ArXiv:2004.10225 [cs]. Retrieved July 14, 2020, from http://arxiv.org/abs/2004.10225

Croucher, S. M., Nguyen, T., \& Rahmani, D. (2020). Prejudice Toward Asian Americans in the Covid-19 Pandemic: The Effects of Social Media Use in the United States. Frontiers in Communication, 5. Frontiers. Retrieved August 12, 2020, from https://www.frontiersin.org/articles/10.3389/fcomm.2020.00039/full

Fauconnier, G. (1985). Mental Spaces: Aspects of Meaning Construction in Natural Language (First English Edition.). Cambridge, Mass: The MIT Press.

Fauconnier, G., \& Turner, M. (2002). The Way We Think: Conceptual Blending And The Mind's Hidden Complexities (Reprint edition.). New York, NY: Basic Books.

Fauconnier, G., \& Turner, M. (2003). Conceptual Blending, Form and Meaning. Recherches en Communication; No 19: Sémiotique cognitive-Cognitive Semiotics; 57-86, 19.

Gee, G. C., Ro, M. J., \& Rimoin, A. W. (2020). Seven Reasons to Care About Racism and COVID-19 and Seven Things to Do to Stop It. American Journal of Public Health, 110(7), 954-955. American Public Health Association.

Liebert, W.-A. (1997). Stop Making Sense! Metaphor and Perspective in Creative Thinking Sessions of Scientists and Scientific Radio Broadcasts. In W.-A. Liebert, G. Redeker, \& L. Waugh (Eds.), Discourse and Perspective in Cognitive Linguistics (pp. 149-183). Amsterdam/Philadelphia: John Benjamins Publishing Company.

Matthiessen, C. M. I. M. (2009). Meaning in the Making: Meaning Potential Emerging From Acts of Meaning. Language Learning, 59(s1), 206-229. John Wiley \& Sons, Ltd.

Musolff, A. (2007). What role do metaphors play in racial prejudice? The function of antisemitic imagery in Hitler's Mein Kampf. Patterns of Prejudice, 41(1), 21-43.

Musolff, A. (2015). Dehumanizing metaphors in UK immigrant debates in press and online media. Journal of Language Aggression and Conflict, 3(1), 41-56.

Norén, K., \& Linell, P. (2007). Meaning potentials and the interaction between lexis and contexts: An empirical substantiation. Pragmatics, 17(3), 387-416.

Oakley, T., \& Coulson, S. (2008). Connecting the dots: Mental spaces and metaphoric language in discourse. In T. Oakley \& A. Hougaard (Eds.), Pragmatics \& Beyond New Series (Vol. 170, pp. 27-50). Amsterdam: John Benjamins Publishing Company. Retrieved July 24, 2020, from https://benjamins.com/catalog/pbns.170.02cou 
Prażmo, E. (2017). Deliberately misleading or unintentionally ambiguous?: A cognitive linguistic view on defective codes of memory. Pragmatics \& Cognition, 24(3), 346372.

Prażmo, E., \& Augustyn, R. (2020). Parasites, Herbivores and Dried Fish: Dehumanising Metaphorical Blends in Japanese. GEMA Online ${ }^{\circledR}$ Journal of Language Studies, 20(2). Retrieved May 30, 2020, from http://ejournal.ukm.my/gema/article/view/37749

Smirnova, A., \& Tolochin, I. (2018). Terrible Angels: Semantic Ambivalence and Polysemy. GEMA Online ${ }^{\circledR}$ Journal of Language Studies, 18(3). Retrieved August 1, 2020, from http://ejournal.ukm.my/gema/article/view/24720

Sperber, D., \& Wilson, D. (1995). Relevance: Communication and cognition. Relevance: Communication and cognition, 2nd ed (pp. viii, 326). Malden: Blackwell Publishing.

Tabri, N., Hollingshead, S., \& Wohl, M. J. A. (2020). Framing COVID-19 as an Existential Threat Predicts Anxious Arousal and Prejudice towards Chinese People (preprint). PsyArXiv. Retrieved July 14, 2020, from https://osf.io/mpbtr

Wilson, D., \& Sperber, D. (2012). Meaning and Relevance (First Edition edition.). Cambridge; New York: Cambridge University Press.

Ziems, C., He, B., Soni, S., \& Kumar, S. (2020). Racism is a Virus: Anti-Asian Hate and Counterhate in Social Media during the COVID-19 Crisis. ArXiv:2005.12423 [physics]. Retrieved July 14, 2020, from http://arxiv.org/abs/2005.12423

\section{ABOUT THE AUTHORS}

Rafał Augustyn, PhD, is Assistant Professor in the Department of Applied Linguistics, Maria Curie-Skłodowska University in Lublin, Poland. Head of the postgraduate study programmes in Certified and Specialised Translation, Interpreting and Law for Certified and Specialised Translators. His academic interests include: cognitive semantics, conceptual metaphor and conceptual blending in specialised discourses, multimodality in film and science communication, and re-conceptualisation in specialised translation.

Ewelina Prażmo, PhD, is currently employed as Assistant Professor at the Department of English and General Linguistics, Maria Curie-Skłodowska University in Lublin, Poland. Her academic interests include: cognitive linguistics, esp. conceptual metaphor, conceptual integration, multimodal blending, and cognitive semantics. 